\title{
Does Stock Market Capitalization Influences Economic Growth in Africa? : Evidence from Panel Data
}

\author{
Mohamed Jalloh ${ }^{1}$ \\ ${ }^{1}$ Economic Policy Analysis Unit (EPAU), Macroeconomic Policy Department, ECOWAS Commission, River Plaza \\ Central Area Abuja, Nigeria. \\ Correspondence: Mohamed Jalloh, Economic Policy Analysis Unit (EPAU), Macroeconomic Policy Department, \\ ECOWAS Commission, River Plaza Central Area Abuja, Nigeria.
}

Received: December 23, 2014

Accepted: January 9, 2015

Available online: January 23, 2015

doi:10.11114/aef.v2i1.641

URL: http://dx.doi.org/10.11114/aef.v2i1.641

\begin{abstract}
The question as to whether stock markets play a significantly positive role in influencing the rate at which economies grow has been seriously debated by economists as well as policymakers. The bone of contention, however, is the fact that the prevailing empirical evidences on the nexus between stock market capitalization and economic growth is still mixed. This study, therefore, aims at providing further evidence on the relationship between stock market capitalization and economic growth using recent data from a sample of African countries with well-functioning stock markets. A dynamic panel estimation approach is employed with a view to assessing the relative impact of stock market capitalization on economic growth in Africa. The results from the study reveal that raising stock market capitalization by a marginal average of $10 \%$ induces growth on average by 5.4\% in countries studied. The positive and significant relationship between stock market capitalization and economic growth as found in this study provides encouraging signals for African countries to explore stock markets as a potential avenue for expediting economic growth. There is therefore a dire need for policymakers in Africa to direct attention towards the implementation of policy measures that will encourage the development of stock markets with a view to promoting economic growth.
\end{abstract}

Keywords: Stock market, Capitalization, Dynamic panel, Economic growth, Africa

\section{Introduction}

Stock markets are well known for playing a very significant role in boosting economic growth through enhancing effective mobilization of savings for investment as well as facilitating capital inflows. They are important in mitigating investors' risks and in the transformation of maturities in the saving-investment nexus (Nissanke, Aryeetey, Hettige, \& Steel, 1995). Stock markets are also important in terms of enhancing productivity by improving the efficiency of financial intermediaries, raising the marginal productivity of capital as well as increasing the savings rate (Montiel, 1996). It has also been argued that well-functioning stock markets enhance the efficiency of the corporate sector through ensuring an effective monitoring of management and exerting corporate controls (Stiglitz, 1985).

In the course of the past three decades, a good number of African countries have experienced some improvements in the development of their stock markets. During the period 1980 to 1999, the number of actively trading stock markets in Africa rose steadily from 8 to 17 (Ndikumana, 2001). However, in 2009, Africa had a total of 29 functioning stock markets across $23^{1}$ countries as against 17 in 1999. A regional stock market ${ }^{2}$ was also established in 1998 by the French-speaking West African countries to serve equity markets in Benin, Burkina Faso, Cote d'Ivoire, Guinea-Bissau, Mali, Niger, Senegal and Togo.

Though quite volatile, returns from emerging African stock markets have been very high. Clark (1998) observes that a good number of African stock markets are highly profitable and frequently ranked among the most rewarding markets in the world. In 1997, for instance, whilst returns to US foreign direct investment (FDI) on average stood at around 25\%

\footnotetext{
1 Algeria, Botswana, Cote d'Ivoire, Cameroon, Egypt, Ghana, Kenya, Libya, Malawi, Mauritius, Morocco, Mozambique, Namibia, Nigeria, Rwanda, South Africa, Sudan, Swaziland, Tanzania, Tunisia, Uganda, Zambia and Zimbabwe

2 Bourse Regional des Valeurs Mobiliéres (BVRM) based in Abidjan, Cote d'Ivoire
} 
in Africa, it was around $16 \%, 12 \%$ and $14 \%$ in Asia, Latin America and all other developing countries respectively (UNCTAD , 1998). Also, Senbet and Otchere (2005) observe that returns from African stock markets averaged about $44.0 \%$ in 2003. This compared favorably to the $30.0 \%$ returns associated with the Morgan Stanley Capital International (MSCI) Global Index, 32.0\% for the MSCI-Europe Index, 26.0\% for the S \& P Index and 36.0\% by the Nikkei Index. In particular, Senbet and Otchere note that stock markets in Ghana, Uganda, Egypt, Kenya, Nigeria and Mauritius recorded phenomenal performance with average returns of over 50.0\%. Owing to the good performance in terms of high returns from African stock markets, Ndikumana (2001) observes that annual FDI inflows to Africa, excluding South Africa, rose from an average of US \$1.2 billion in 1981-1985 to US \$2.9 billion in $1986-1991$, and US \$5.3 billion in 1992-1998.

In spite of the good performance of African stock markets, the bone of contention, however, is the fact that the empirical evidences on the nexus between stock markets development and economic growth remained unresolved. Corbett and Jenkinson (1994) found that the contribution of stock markets to corporate investment financing was negative in the UK but slightly positive in the United States during the 1970s and 1980s. In two other separate studies, Akyuz (1993) and Singh (1997) both found that unfavorable economic shocks from the interaction between stock markets and foreign exchange markets resulted in macroeconomic instability which in turns adversely affect economic growth. On account of the mixed empirical evidences on the link between stock market development and economic growth, the key objective of this study is to re-examine the relationship between stock market development and economic growth using recent data from selected African countries with functioning stock markets. Specifically, this study seeks to assess the impact of stock market capitalization on economic growth.

Following the introduction, the remaining part of the paper is divided into five sections as follows: Section 2 presents an overview on stock market capitalization and growth performance in selected Africa countries. In section 3, the study provides a brief review of the relevant literature. Section 4 presents an appropriate methodology with particular focus on the model specification and estimation techniques employed by the study. Whilst section 5 presents and interprets the estimation results, section 6 provides some concluding remarks based on the findings from the study

\section{Stock Market Capitalization and Economic Growth in Selected African Countries.}

African stock markets have demonstrated diverse experiences in terms of market capitalization over the past two decades. Between 1990 and 1995, only five African countries with functional stock markets recorded an annual average market capitalization in excess of $10.0 \%$ of GDP. These countries include Ghana, Kenya, Mauritius, South Africa and Zimbabwe. However, between 1996 and 2000, six other African countries including Botswana, Cote d'Ivoire, Egypt, Morocco, Namibia and Tunisia recorded an average annual market capitalization in excess of $10.0 \%$ of GDP, bringing the total number of countries with market capitalization in excess of $10.0 \%$ of GDP to eleven. This was partly because of a steady rise in the number of listed companies following a series of financial reforms programs implemented with a view to enhancing the efficiency of financial markets in these countries. On the contrary, however, Nigeria, Tanzania, Uganda and Zambia recorded an annual average market capitalization of less than $10.0 \%$ of GDP by end 2000 .

Table 1. Capitalization of Selected African Stock Markets as \% of GPD (1990 - 2012.)

\begin{tabular}{|c|c|c|c|c|c|c|c|c|c|c|c|c|c|c|}
\hline Country & $1990-1995$ & $1996-2000$ & 2001 & 2002 & 2003 & 2004 & 2005 & 2006 & 2007 & 2008 & 2009 & 2010 & 2011 & 2012 \\
\hline Botswana & 7.5 & 14 & 23.1 & 31.7 & 28.4 & 28.4 & 24.5 & 39 & 53.8 & 32 & 42.3 & 29.7 & 26.9 & 31.6 \\
\hline Cote d'Ivoire & 5.2 & 11.2 & 11 & 11.6 & 12 & 13.5 & 14.2 & 23.9 & 42.2 & 30.2 & 26.7 & 31 & 26.1 & 31.7 \\
\hline Egypt & 8.2 & 28.3 & 24.9 & 29.7 & 32.6 & 48.9 & 88.8 & 87 & 107 & 52.7 & 47.6 & 37.7 & 20.6 & 22.1 \\
\hline Ghana & 12.9 & 15.7 & 9.9 & 12 & 18.7 & 29.8 & 15.5 & 15.8 & 9.6 & 11.9 & 9.7 & 11 & 7.8 & 8.5 \\
\hline Kenya & 16.8 & 12.9 & 8.1 & 10.8 & 28 & 24.2 & 34.1 & 50.6 & 49.1 & 35.8 & 35.2 & 44.9 & 30.3 & 36.3 \\
\hline Mauritius & 22.2 & 37.9 & 23.4 & 27.9 & 34.9 & 37.3 & 41.7 & 53.5 & 72.7 & 35.7 & 53.6 & 76.6 & 68.1 & 67.6 \\
\hline Morocco & 9.7 & 32.7 & 24.1 & 21.3 & 26.4 & 44 & 45.7 & 75.2 & 100 & 74 & 69.2 & 76.2 & 60.6 & 54.8 \\
\hline Namibia & 3.3 & 14.6 & 4.2 & 5.1 & 6.2 & 6.7 & 5.7 & 6.8 & 8.0 & 7.0 & 9.6 & 10.6 & 9.1 & 10 \\
\hline Nigeria & 7.4 & 9.3 & 12.2 & 9.7 & 14 & 16.5 & 17.2 & 22.6 & 51.9 & 23.9 & 19.7 & 13.9 & 9.5 & 12.3 \\
\hline South Africa & 138 & 160 & 118 & 166 & 159 & 208 & 229 & 274 & 291 & 180 & 248 & 175 & 130 & 159 \\
\hline Tanzania & 0 & 2.2 & 3.8 & 6.5 & 5.7 & 5.2 & 4.2 & 3.8 & 4.3 & 6.2 & 5.8 & 5.5 & 6.4 & 6.4 \\
\hline Tunisia & 10 & 13.7 & 10.4 & 9.2 & 9 & 8.5 & 8.9 & 12.9 & 13.8 & 14.2 & 20.9 & 24.1 & 20.8 & 19.4 \\
\hline Uganda & 0 & 0 & 0.6 & 0.8 & 0.7 & 1.2 & 1.1 & 1.2 & 4.7 & 21.6 & 25.3 & 11.2 & 49.9 & 36.4 \\
\hline Zambia & 0.5 & 9.9 & 6.9 & 6.3 & 17.3 & 13.8 & 13.8 & 11.1 & 20.3 & 22.6 & 25.3 & 11.2 & 49.9 & 36.4 \\
\hline Zimbabwe & 21.6 & 31.8 & 118 & 247 & 86.9 & 33.4 & 41.7 & 488 & 101 & 87.4 & 62.4 & 154. & 123 & 121 \\
\hline
\end{tabular}

Source: World Bank Development Indicators 2014. It should be noted that at the time of carrying out this work, data on stock market capitalization was only available up to 2012.

During the period 1990 to 2012, the highest performance in terms of market capitalization was recorded by Mauritius, 
Morocco, South Africa and Zimbabwe ( see Table 1). In the case of Mauritius, market capitalization rose from $23.4 \%$ of GDP in 2001, attained a peak of 72.7\% in 2007 and eventually declined to 67.6\% of GDP in 2012. For Morocco, market capitalization initially rose from $24.1 \%$ of GDP in 2001 to attain a peak of $100.4 \%$ in 2007, and again declined steadily to $54.8 \%$ in 2012 . A similar pattern is being exhibited by South Africa where market capitalization rose initially from $118.0 \%$ of GDP in 2001, reached a peak of 291.3\% in 2007, and thereafter plummeted to around $159.3 \%$ in 2012. The observed decline in market capitalization after 2007 in these countries was partly triggered by the global financial crisis in 2008 that started from the United States of America. Notwithstanding, however, South Africa recorded the best performance in terms of market capitalization over the period under review. For Zimbabwe, market capitalization was somehow quite volatile over the period. In 2001, Zimbabwe had a market capitalization of $117.6 \%$ of GDP which suddenly jumped to around $246.5 \%$ in 2002 , further jumped to $487.8 \%$ in 2006 , but thereafter, steadily declined to around $120.5 \%$ of GDP in 2012 (see Figure 1).

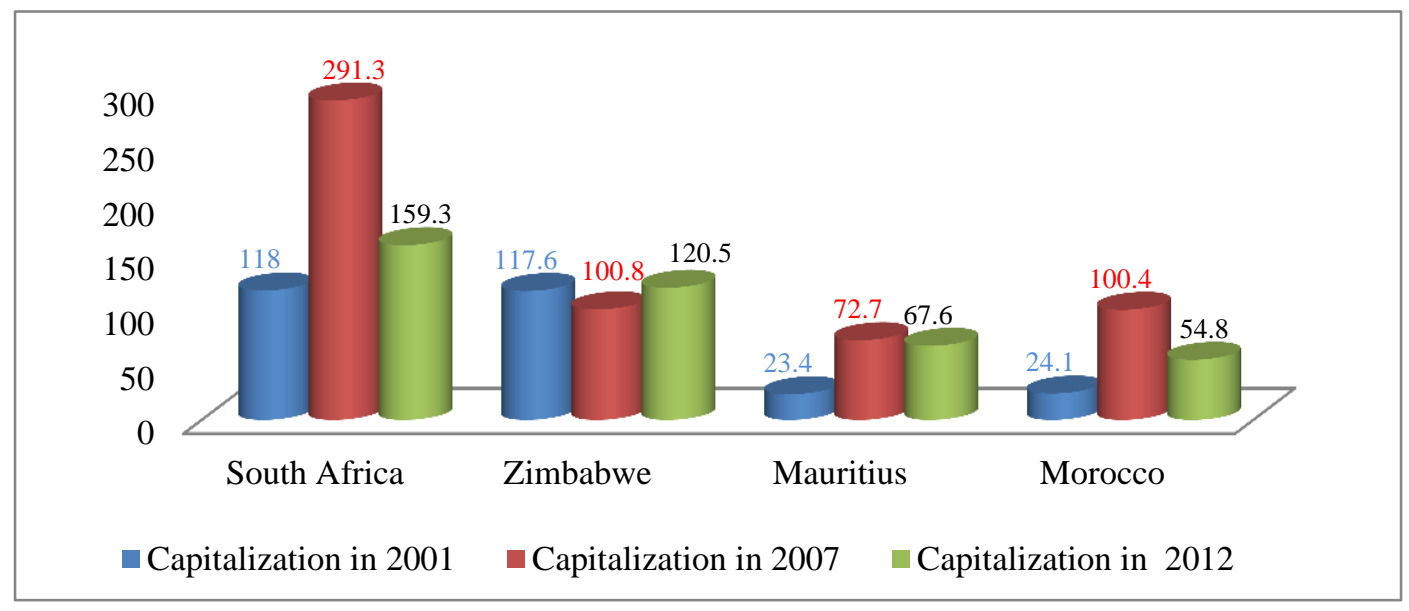

Figure 1. Market Capitalization for Mauritius, Morocco, South Africa and Zimbabwe

Botswana, Code d'Ivoire, Kenya and Zambia constitutes the second group of countries with good performance in terms of market capitalization following Mauritius, Morocco South Africa and Zimbabwe. Botswana's market capitalization rose steadily from $23.1 \%$ of GDP in 2001, reached a zenith of 53.8\% in 2007, and thereafter fell gradually to $31.6 \%$ of GDP in 2012. Similarly, Kenya with market capitalizations of 8.1\% of GDP in 2001, attained a peak of 50.6\% in 2006 and then fell to around 36.3\% in 2012( see Table 1 and Figure 2). Similar patterns were exhibited by stock markets in Code d'Ivoire and Zambia.

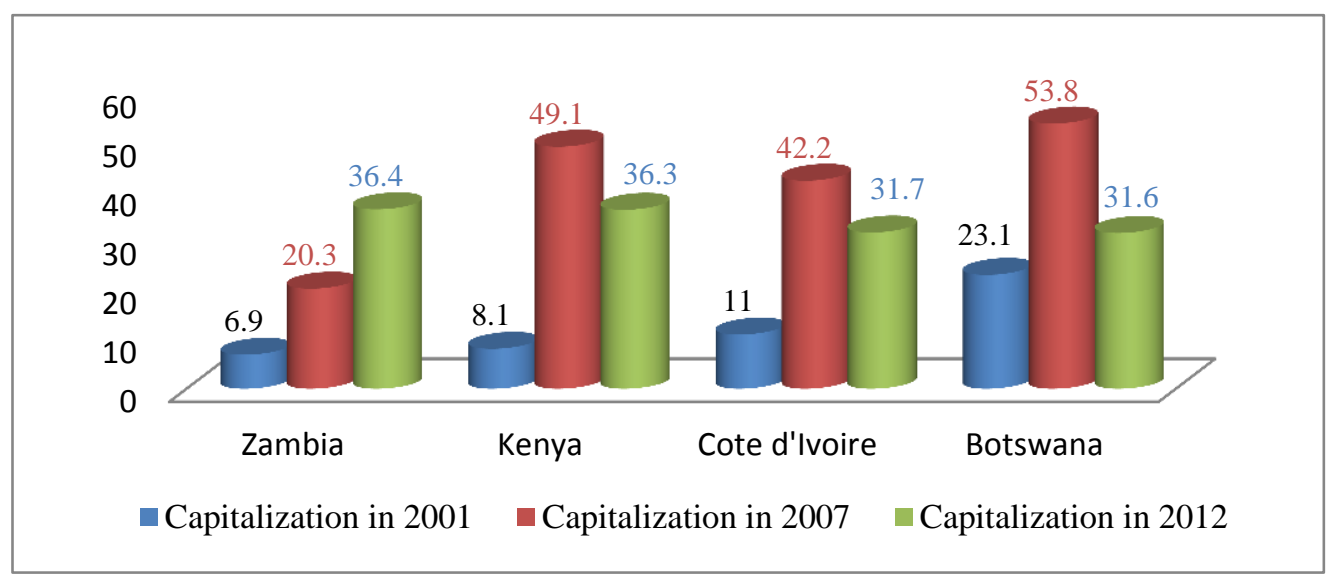

Figure 2. Market Capitalization for Botswana, Cote d'Ivoire, Kenya and Zambia.

The other set of countries with moderate performance in terms of market capitalization over the period under review include Egypt, Ghana, Namibia, Nigeria and Tunisia. Egypt, with a market capitalization of $24.9 \%$ of GDP in 2001, attained a peak of $106.8 \%$ in 2007, and thereafter plummeted to $22.1 \%$ of GDP in 2012 (see Figure 3). Nigeria too had a similar experience like Egypt as market capitalization rose initially from 12.2\% in 2001 to attain a peak of 51.9\% in 2007 and thereafter plunged to around 12.3\% in 2012. For Ghana, Namibia, and Tunisia, market capitalization grew 
steadily with very little swings over the period under review.

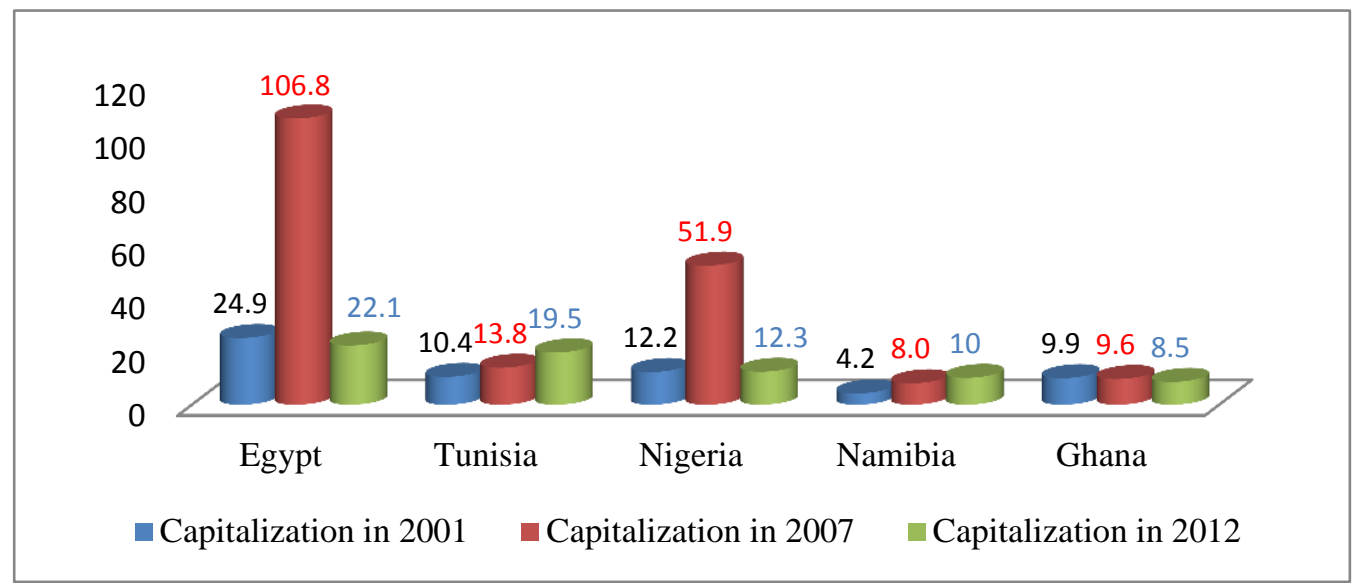

Figure 3. Market Capitalization for Egypt, Ghana, Namibia, Nigeria and Tunisia.

Following the above analysis, efforts are also being made to establish some relationships between market capitalization and growth in selected African countries using data for the years 2007 and 2012. The choice for comparing stock market performance and growth using these years was based on the fact that 2007 was the year preceding the global financial crisis whilst 2012 was the year when most countries started gaining some amount of macroeconomic stability from the effects of the global financial crisis in Africa. As can be observed from Figure 4, with the exception of Tunisia, Uganda and Zimbabwe, market capitalizations were higher in 2007 than in 2012 for all other countries in the sample.



Figure 4. Market Capitalization in Selected African Countries in 2007 and 2012

By way of comparing stock market capitalization and economic growth, Figure 5 demonstrates that, with the exception of Cote d'Ivoire, Morocco, and Zimbabwe, growth rates were also higher in 2007 in all other countries than in 2012. This observation implicitly suggests that higher levels of stock market capitalization could be associated with higher prospects for economic growth in the sample of countries studied( see Figure 5). In the Case of Cote d'Ivoire and Zimbabwe, 2007 was a particularly difficult year as both countries were facing serious economic challenges arising from the civil conflict in Cote d'Ivoire and macroeconomic instability in Zimbabwe. 


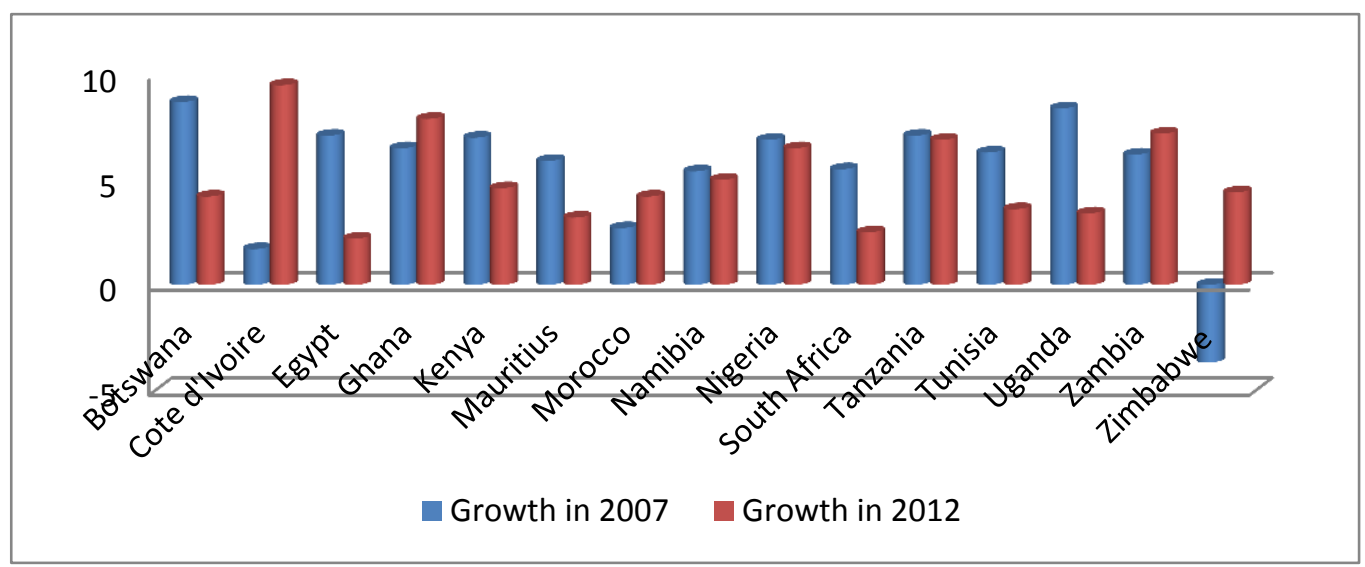

Figure 5. Growth Rates in Selected African Countries for 2007 and 2012.

\section{Literature Review}

The theoretical foundation linking financial development and economic growth remains a controversial subject amongst economists as well as policymakers. Schumpeter (1911) maintains that the financial intermediation services offered by the financial sector encourage technological innovation which in turns boosts economic growth. Similarly, Goldsmith (1969) and McKinnon (1973) show a positive relationship that flows from financial development to economic growth. On the contrary, Robinson (1952) was of the view that financial development is only a by-product of economic growth. He argues that the development of the financial sector is a direct outcome of a country's growth performance over time. Robinson contends that as per capita income rises with economic growth, it will encourage the development of the financial sector by enhancing its ability to effectively mobilize financial resource from the corresponding increase in savings, thereby boosting its financial intermediation services. However, Singh (1997) purports that financial markets development may likely turn out to be an obstruction to economic growth when they cause volatility and subsequently discourage risk-averse investors from undertaking investment projects

A good number of economists have advanced plausible arguments on the role of the financial sector in identifying viable investment opportunities aimed at spurring economic growth. By putting in place an effective mechanism to mobilize savings for productive investment as well as facilitating capital inflows from foreign investors, the financial sector certainly plays an important role in encouraging investment in both physical and human capital, thereby enhancing productivity and hence economic growth. To that end, King and Levine (1993b) note that the financial sector plays a major role in the evaluation of prospective entrepreneurs for the financing of the most promising ones. They further argued that better financial systems enhance the probability of successful innovations, thereby raising prospects for the acceleration of economic growth. They further maintained that well-functioning financial institutions play a significant role in terms of evaluating, managing and funding entrepreneurial activities that leads to productivity growth. In another development, Grossman and Helpman (1991) contend that well-functioning financial systems enable entrepreneurs to undertake very innovative activities that influence growth through productivity enhancement. The argue that, owing to their ability in terms of evaluating entrepreneurs, pooling financial resources and diversifying investors' risks, financial systems directly affect entrepreneurial activities.

Since the early 1990s, there was an expanding theoretical literature on the relationship between stock markets development and long run growth though with little empirical evidence. In two separate studies, Levine (1991) and Bencivenga et al (1995) propose models in which more liquid equity markets reduce the disincentives to invest in long-term projects. They maintained that, well-functioning stock markets will ensure that investors can sell their stakes in the project if they need their savings before the project matures. In the absence of financial intermediaries, individual investors must allocate their portfolios between capital and currency to maximize expected utility. Greenwood and Jovanovich (1990) purport the role of financial intermediaries in pooling funds and acquiring information that enables them to allocate capital to its highest valued use, thereby raising the average return to capital. Furthermore, Levine (1991) develops an endogenous growth model in which stock markets are assumed to permanently accelerate growth by reducing liquidity and productivity risk. The model further assumed that in the absence stock markets, risk-averse investors might be constrained from investing in a firm because of firm-specific productivity shocks. By insuring investors against idiosyncratic risk, stock markets enable investors to hold diversified portfolios. This helps in enhancing the amount of financial resources allocated to the firm. Furthermore, liquidity may force agents to prematurely sell assets at a low liquidation return. Stock markets generally have the tendency to reduce that risk since ownership can be easily transferred at more preferable conditions. Thus, the reduction of liquidity risk is highly likely to 
encourage investment and thereby indirectly boosts economic growth. In such a situation, untimely removal of a firm's capital can be certainly avoided to prevent unnecessary shocks to technological innovation. This has the tendency of raising a firm's productivity and thereby stimulates growth. This model further demonstrates that impeding or taxing financial market activity can adversely affect long-term growth.

With respect to investment decisions and the capital structure of firms, two key studies have shown the absence of a perfect substitution between internal finance from retained earnings and external finance from bonds, equity or bank credit studies (Mayer, 1989; and Fazzari, Hubbard \& Petersen, 1988). On the basis of this framework, investment decision can be influenced by the availability or non-availability of appropriate financial instruments. From a macroeconomic viewpoint, the sensitivity of investment to liquidity and corporate retained earnings ${ }^{3}$ may affect firms that heavily rely on internal finance. Issues relating to financial constraints on investment decisions as well as the nexus between corporate capital structures and the financial decisions of the real economy are explained in different versions of models of asymmetric information, adverse selection, moral hazard, agency and transaction costs and incentive effects (Stiglitz \& Weiss, 1981). In the Stiglitz-Weiss models, it is argued that information asymmetric might result in making interest rate policy inefficient in the process of discriminating good from bad borrowers. In such circumstances, firms may face binding financial constraints in the capital markets as credit rationing and quantitative constraints are imposed by creditors.

From an empirical point of view, a number of studies on the relationship between stock market development and economic growth have been carried out since the 1990s. The study by Levine and Zervos (1998a) use various indicators of stock market development from a cross-section of 42 countries over the period 1976 - 1993 and found that the initial level of stock market liquidity and bank credits are positively and significantly correlated with future rates of economic growth, capital accumulation, and productivity growth. The findings from this study were consistent with those of Levine (1991), Holmstrom and Tirole (1993), and Bencivenga, Smith \& Starr (1995) which demonstrate that stock market liquidity facilitates long-run growth . This study, however, disputes models that emphasize the negative aspects of stock markets liquidity (Bhide, 1993). Levine and Zervos (1998a) further argue that the link between stock markets, banks and economic growth runs most robustly through productivity growth, rather than physical capital accumulation. Using a sample of 21 emerging markets from developing countries, Mohtadi and Agarwal (2001) found a positive relationship between several indicators of stock market performance and economic growth.

The studies by Rajan and Zingales (1998), Demirgüç-Kunt and Maksimovic (1996), Jayarantne and Strahan (1996) were amongst the few that employ a microeconomic approach in analyzing the link between financial development and economic growth. In particular, Rajan and Zingales (1998) examine whether financial development facilitates economic growth by analysing the relationship between industry level growth across countries and financial development. Their study found that firms that are in need of external finance develop disproportionately faster in countries with more developed financial markets. Demirgüç-Kunt and Maksimovic (1996) contend that firms with easy access to more developed stock markets grow faster than those that cannot. In another development, Jayarantne and Strahan (1996) show that financial development can directly affect growth by studying the relaxation of bank branch restrictions in the United States. The result of their study indicates that the rates of real per capita growth in income and output increase significantly following intrastate branch reform. Few other studies employ firm level data to examine whether financial development eases financing constraints (Love, 2003; Dyck \& Zingales, 2004; and Beck, Demirgüç-Kunt \& Maksimovic, 2005). Love (2003) argues that greater financial development reduces the link between the availability of internal funds and investment. This study reveals that the sensitivity of investment to internal funds is greater in countries where the financial system is poorly developed as compared to those with sound financial systems. The study also shows that financial development is rather more effective in easing the financial constraints of small firms. Dyck and Zingales (2004) estimate the value of control in 393 control transactions across 39 countries over the period 1990 2000. Their results indicate that the benefit of control is greater in countries with poorly-developed financial systems. Using a different data set and methodology to investigate the impact of financial development on firms financing constraints, Beck , Demirgüç-Kunt and Maksimovic (2005) show that financial development mitigates the impact of various obstacles to firm growth and that small firms benefit most from financial development.

Despite the fact that a good number of country specific studies have broadly attempted to examine the link between stock market development and economic growth, none of these studies have examined the impact of market capitalization using recent data from a panel of African countries. This study - which employs a dynamic panel approach - is expected to contribute to the burgeoning literature on financial sector development and economic growth by examining the impact of market capitalization on economic growth in Africa.

\section{Methodology and Data Sources}

\footnotetext{
${ }^{3}$ which in turn are dependent on the business cycle and macroeconomic instability
} 


\subsection{Model Specification and Estimation Techniques}

The study adopted an endogenous growth framework in specifying a model that best captures the impact of stock market capitalization on economic growth (Romer, 1989; King \& Levine, 1993; and Pagano, 1993). Given the growing empirical evidences supporting the positive effects of financial development on economic growth (Levine, Loayza \& Beck, 2000; Ndikumana, 2000; Gelbard \& Leite, 1999; Odedokun, 1996; and Jalloh, 2014), we control for non-financial factors that influence long run growth, and generalize the specification of a growth equation that accounts for the effects of financial development on economic growth as follows:

$$
\begin{gathered}
\ln \left(y_{i t}\right)=\alpha+\beta_{1} \ln \left(F D_{i t}\right)+\beta_{2} \ln \left(F I N_{i t}\right)+\beta_{3} \ln \left(I R S_{i t}\right)+\beta_{4} \ln \left(S M C_{i t}\right)+\lambda_{1} \ln \left(R E R_{i t}\right)+\lambda_{2} \ln \left(S A V_{i t}\right)+ \\
\lambda_{3} \ln \left(F D I_{i t}\right)+\lambda_{4} \ln \left(P S I_{i t}\right)+\lambda_{5} \ln \left(I N F_{i t}\right)+\lambda_{6} \ln \left(H C_{i t}\right)+\eta_{i}+\varepsilon_{i t}
\end{gathered}
$$

Where the explanatory variables are define as follows:

$\begin{aligned} \mathrm{FD} & =\text { financial depth ( ie M2/GDP) } \\ \mathrm{FIN} & =\text { financial intermediation (ratio of quasi-liquid liabilities to GDP) } \\ \mathrm{IRS} & =\text { interest rate spread (the difference between the lending and deposit rates of commercial banks) } \\ \mathrm{SMC} & =\text { Stock market capitalization } \\ \mathrm{RER} & =\text { the real exchange rate } \\ \mathrm{SAV} & =\text { gross national savings as a share of GDP } \\ \mathrm{FDI} & =\text { foreign direct investment as a share of GDP } \\ \mathrm{PSI} & =\text { public sector investment as a share of GDP } \\ \mathrm{INF} & =\text { inflation } \\ \mathrm{HUM} & =\text { human capital (measured as the rate of secondary school enrolment) } \\ \boldsymbol{\beta}_{\boldsymbol{i}} & =\text { measures the relative effects of financial factors on growth } \\ \boldsymbol{\lambda}_{\boldsymbol{i}} & =\text { set of parameters measuring the relative effects of the control variables. }\end{aligned}$

Equation (1) above is the basis for estimating the relationship between growth in GDP and our measures of financial development including stock market capitalization. As shown in equation (1), if the unobserved country-specific effects, $\eta_{i}$, are not correlated with the explanatory variables, then the application of the pooled OLS estimator will produce efficient estimates. However, in the event that a strong correlation exists between the unobserved individual effects, $\eta_{i}$ and the explanatory variables, the pooled OLS estimator will be biased and inefficient. In such a situation, the fixed effects model will be more appropriate in estimating the model's parameters. In the event that the assumptions of the standard random effects hold but that the model does not actually contain unobserved effects, then the pooled OLS will not only be efficient but the associated statistics will also be asymptotically valid. In order to test for the absence of unobserved effect, this study employs a simple AR(1) test for serial correlation. The appropriateness of this test is premised on the fact that the idiosyncratic errors are serially uncorrelated under the null $H_{0}: \sigma_{\eta}^{2}=0$, when the explanatory variables are exogenous. Detecting serial correlation amongst the idiosyncratic errors using this approach implies the presence of unobserved effect. In a good number of applications, the whole point of using panel data is to allow for the unobserved effects, $\eta_{i}$, to be arbitrarily correlated with the set of explanatory variables, thus necessitating the application of a fixed effects estimation procedure. In the current study, the choice for using either the fixed effects or random effects model in the levels estimation will be based on the Hausman specification test. A larger value of the Hausman test statistic leads to the rejection of the null hypothesis that the individual-specific effects are uncorrelated with the explanatory variables and to the conclusion that fixed effects are present.

Following Levine et al (2000) and Beck et al (2000), the study also employs a dynamic panel approach to address potential problems of endogeneity in the data using the procedures by Arrelano and Bond (1991), Arrelano and Bover ( 1995) and Blundell and Bond ( 1998). Such a dynamic panel setting is developed by applying first difference transformation as shown in the equations below:

$$
y_{i, t}-y_{i, t-1}=(\alpha-1) y_{i, t-1}+\beta^{\prime} X_{i, t}+\eta_{i}+\varepsilon_{i, t}
$$

Where $y_{i, t}-y_{i, t-1}$ is the growth rate in real GDP per capita, $X_{i, t}$ is the set of explanatory variables, including our measures of financial development, $\boldsymbol{\eta}_{i}$ is the unobserved country-specific effect, and $\varepsilon_{i, t}$ is the error term. We proceed by rewriting equation (2) as:

$$
y_{i, t}=\alpha^{\prime} y_{i, t-1}+\beta^{\prime} X_{i, t}+\eta_{i}+\varepsilon_{i, t}
$$

Now, by taking the first difference of both the endogenous and exogenous variables in equation (4.3), we have:

$$
y_{i, t}-y_{i, t-1}=\alpha^{\prime}\left(y_{i, t-1}-y_{i^{\prime} t-2}\right)+\beta^{\prime}\left(X_{i, t}-X_{i, t-1}\right)+\left(\varepsilon_{i, t}-\varepsilon_{i, t-1}\right)
$$


As can be observed from equation (4) above, the lagged difference in per capita GDP is correlated with the error term, which by implication of the potential endogeneity of the explanatory variables $\mathrm{X}$, provokes the use of instrumental variables. In order to address this problem, the system difference estimator uses the lagged level of the explanatory variables as instruments under the assumption that the error term is serially uncorrelated and that the lagged level of the explanatory variables are weakly exogenous. Following Blundell and Bond (1998), this study employs two specification tests. The first is the Sargan test of over-identification restriction to test the validity of the instruments. The second is a test of second order serial correlation of the error term, which tests whether the error term in the differenced equation model follows a first order moving average process.

\subsection{Data Sources}

The data set used in this study was collected from the International Financial Statistics and the World Bank Development Indicators 2014.

\section{Presentation and Interpretation of Results}

In order to assess the impact of stock market capitalization on economic growth, data on key variables of interest including stock market capitalization were collected from a cross-section of 15 African countries with well-functioning stock markets over the period 2001 - 2012. The criterion used in selecting countries to be included in the analysis was purely based on availability of complete data on the relevant variables required to carry out the estimation of the specified model as presented in the previous section. On that note, the countries from which complete data on stock market capitalization and other relevant variables were collected over the period 2001 and 2012 include Botswana, Cote d'Ivoire, Egypt, Ghana, Kenya, Mauritius, Morocco, Namibia, Nigeria, South Africa, Tanzania, Tunisia, Uganda, Zambia and Zimbabwe. As earlier noted in the methodology section, the study made use of the Hausman specification test in choosing between the fixed effects and random effects model in our estimating of the levels equations. The estimation of the parameters of the dynamic panel model was based on the Arellano -Bond approach using the Stata command 'xtabond'. The estimates from the Hausman specification test are shown in the lower section of Table 2.

From the results of the Hausman specification test presented in Table 2, the individual unobserved country-specific effects are uncorrelated with the explanatory variables, suggesting that the fixed effects model is preferable to the random effects model for the levels regression estimates. Hence for the levels estimates, we only consider the results from the fixed effects estimates in our discussion of findings. Furthermore, the results from the Sargan tests as presented in Table 2 indicate that the instruments used for correcting potential endogeneity in the data sect used in estimating the dynamic panel regression are valid. Finally, the second order serial correlation test for the residuals of the dynamic panel regression shows no serious problem of serial correlation.

As noted in the above paragraph, we only discuss the results from the fixed effects model and those of the dynamic panel. This is because; the Hausman specification test indicates that the results from the random effects model are not as robust as those of the fixed effects model. Since the estimates from the dynamic panel model account for the relative impact of the exogenous variables on growth rate of income per capita, discussions of the results with respect to relative effects will be based on the coefficients of the dynamic panel model. From the results presented in Table 2, it could be observed that the coefficient of the variable representing financial deepening (FD) is positive and significant at the 5\% level for both the fixed effects and dynamic model. This, therefore, indicates that financial deepening has a positive and significant effect on economic growth. The results from the dynamic model thus implies that enhancing financial deepening by $10.0 \%$ will induce growth in GDP by a margin of about $2.5 \%$.

Table 2. Panel Estimation Results: Growth in GDP as the Dependent Variable

\begin{tabular}{|c|c|c|c|}
\hline Variables & Fixed Effect Model & Random Effect Model & Dynamic Model \\
\hline Constant & $18.195(2.48)^{*}$ & $16.528(2.02)^{*}$ & \\
\hline$y_{-1}$ & & & $0.04071(0.33)$ \\
\hline FD & $0.3486(2.97)^{* *}$ & $0.9545(3.18)^{* *}$ & $0.24808(2.04)^{*}$ \\
\hline FIN & $0.2251(1.96)^{*}$ & $0.1088(1.82)$ & $0.2082(2.53) * *$ \\
\hline IRS & $-0.1076(-1.96)^{*}$ & $-0.4622(-3.21)^{* *}$ & $-0.2482(-2.53) * *$ \\
\hline RER & $0.1256(2.51)^{* *}$ & $0.1623(3.08)^{* *}$ & $0.0849(1.97)^{*}$ \\
\hline INF & $-0.0435(-1.69)$ & $-0.01577(-1.48)$ & $-0.01264(-1.06)$ \\
\hline SAV & $0.0324(0.10)$ & $0.0021(0.05)$ & $0.026(0.08)$ \\
\hline FDI & $-0.0141(-2.51)^{* *}$ & $-0.01678(-2.13)^{*}$ & $-0.0165(-2.05)^{*}$ \\
\hline PSI & $0.2543(0.20)$ & $0.1327(0.12)$ & $-0.0925(-0.07)$ \\
\hline SMC & $0.4765(2.01)^{*}$ & $0.2452(1.43)$ & $0.5452(2.11)^{*}$ \\
\hline HUM & $0.0578(2.26)^{*}$ & $0.1293(3.89)^{* *}$ & $0.0756(2.68)^{* *}$ \\
\hline No. of Obs. & 180 & 180 & 180 \\
\hline
\end{tabular}


$\mathrm{R}^{2}$

F-Statistics

Hausman Test

Test for Second order Serial correlation

Sargan Test
0.7812

$F(13,172)=2.57(0.0055)$ $\mathrm{Ch}$



0.7563

Wald Chi2(13) $=79.50$

$(0.000)$

Chi2 $(14)=121.37(0.000)$



\begin{tabular}{|c|}
\hline $\mathrm{H}_{0}$ : No autoco \\
\hline Chi 2(22) $=39.8(0.867)$ \\
\hline
\end{tabular}

$\mathrm{H}^{\mathrm{H}} \stackrel{\text { No autocorrelation }}{=}-3.61(0.0003)$

Chi 2(22) = 39.8(0.867)

Note : where the variables are expressed in log form and $t$-values are reported in parenthesis, where $(*)$ and $(* *)$ implies significance of coefficient at the 5\% and $1 \%$ level respectively. The variables entering the Dynamic model are in first difference and their coefficients are interpreted as growth elasticities. Both the fixed effects and random effects models are in levels. The dynamic model is based on the Arellano-Bond Estimation procedure.

The coefficient of the financial intermediation (FIN) variable is positive and highly significant in the dynamic panel model. In terms of relative effects, the results from the dynamic panel estimation demonstrate that raising the level of financial intermediation by $10.0 \%$ will induce growth in per capita income on average by a margin of $2.1 \%$. This finding is consistent with those of Beck et al (2000), Odedokun (1996) and Spears (1992) who found that financial intermediation positively drives economic growth.

On the relationship between interest rate spread (IRS) and growth, the results as presented in Table 2 show a significantly negative relationship between interest rate spread and growth in income per capita from both the fixed effects and dynamic panel estimates. In particular, the results from the dynamic panel estimation show that raising interest rate spread by $10.0 \%$ will reduce growth in income per capita by a margin of $2.5 \%$. The negative relationship between interest rate spread and growth in income per capita as revealed in this study may not be surprising because, the higher the spread between the lending and deposit rates the higher the cost of capital, which in turn reduces returns from investment and hence growth.

The coefficient of the real exchange rate (RER) variable is positive and significant at the $5 \%$ level from both the fixed effects and the dynamic panel estimates. This implies that an improvement in the real exchange rate promotes growth in income per capita. In particular, the coefficient of the real exchange rate variable as shown in the dynamic model indicates that a $10.0 \%$ improvement in the real effective exchange rate enhances growth in income per capita on average by a margin of $0.8 \%$. This is not surprising because the real exchange rate is very crucial to the development of the domestic economy as it establishes market incentives to exports and the level of protection for domestic industries. Secondly, a stable nominal exchange rate provides a potential monetary anchor and a powerful anti-inflationary mechanism.

The coefficient of the foreign direct investment (FDI) variable is negative and statistically significant for both the fixed effects and dynamic panel estimates. In terms of its impact, the results from the dynamic model revealed that enhancing foreign direct investment by $10.0 \%$ impedes growth in income per capita by a margin of $0.2 \%$. This result is in line with that of Streeten (1973) who argues that foreign direct investment is less likely to contribute to public revenues as transnational corporations are often able to avoid taxes through mechanisms such as transfer pricing. Moreover, foreign direct investment is more likely to use inappropriate capital intensive technology and less likely to reinvest profits in the host country.

The coefficient of stock market capitalization (SMC) variable is positive and statistically significant. In particular, the estimates from the dynamic model reveal that raising stock market capitalization by a margin of $10.0 \%$ will promote growth in income per capita by a margin of 5.4\% in countries studied. This finding is consistent with the study by Demirgüç-Kunt and Maksimovic (1996) who purport that firms with access to more developed stock markets grow faster. Similarly, the study by Levine and Zervos (1998a) show that the initial level of stock market liquidity and bank credits are positively and significantly correlated with future rates of economic growth, capital accumulation, and productivity growth. Thus the finding from this study reveals that stock market development is important for boosting economic growth in Africa.

Finally, the relationship between the variable representing human capital (HUM) and growth in income per capita is positive and statistically significant. This, therefore, implies that developing human capital is very important for boosting economic growth. This is because; in most African countries, the average quality of human capital is still low owing to the low proportion of its people that can afford to access high quality education. Because the quality of education is very low in these countries, a marginal improvement in human capital through higher education will have significant impact on growth through increase productivity of skilled labour. This is because, there is a large stock of unexploited growth related technologies in these countries such that any marginal increase in the use of appropriate technology through higher educational attainment will result in increasing the average productivity of workers. Thus, by increasing the supply of quality workers through additional training, human capital development will raise total productivity at an increasing rate, thereby accelerating economic growth in these countries.

\section{Conclusion}

This study, which specifically aims at examining the relationship between stock markets capitalization and economic growth in Africa, uses an endogenous growth framework to specify a model that better capture among others the effect of Stock Market development on growth. Data on stock market capitalization and other financial indicators were collected from a cross-section of 15 
African countries with functioning stocks markets. A panel estimation approach was employed using the Hausman Specification test whose results indicate a rejection of the null hypothesis that individual unobserved country-specific effects are uncorrelated with the explanatory variables, suggesting a preference for the fixed effects over the random effects model. The results from the Sargan tests for over-identification restrictions also indicate that the instruments are valid in the dynamic regressions. The findings from this study reveal that the development of stock markets in Africa is very crucial in expediting an effective approach for promoting sustainable growth in the Sub-region. The results from this study reveal that raising stock market capitalization on average by a margin of $10.0 \%$ will induce economic growth by a margin of approximately $5.4 \%$ in countries studied. A direct policy implication emerging from this study is that, there is an urgent need for African countries to promote stock market development in order to explore the potential growth-inducing effects of well-functioning stock markets. Thus this study's findings have provided some encouraging signals for African countries to explore stock markets development as potential avenues for expediting economic growth. A key limitation of this study, however, is that, it fails to examine the impact of other stock market development indicators like liquidity and turnover on economic growth. This should therefore be the focus of future research in further assessing the impact of stock market development on economic growth in Africa.

\section{References}

Akyuz, Y. (1993). Financial Liberalization: The Key Issues in Finance and Real Economy, edited by Yilmaz Akyuz and Gunther Held. Santiago: United Nations University.

Arellano, M \& Bond, S. (1991). Some Tests of Specification for Panel Data: Monte Carlo Evidence and an Application to Employment Equations, The Review of Economic Studies, 58(2), 277 - 297. http://dx.doi.org/10.2307/2297968

Arellano, M, \& Bover, O. (1995). Another Look at the Instrumental-Variable Estimation of Error-Components Models, Journal of Econometrics, 68(1), 29-51. http://dx.doi.org/10.1016/0304-4076(94)01642-D

Beck, T. A., Levine, R., \& Loayza, N. (2000). Finance and the Sources of Growth, Journal of Financial Economics, 58(1), $261-300$. http://dx.doi.org/10.1016/S0304-405X(00)00072-6

Beck, T. A, Demirgüç-Kunt, \& Maksimovic, V. (2005). Financial and Legal Constraints to Firm Growth: Does Size Matter, Journal of Finance, 60, 137-177. http://dx.doi.org/10.1111/j.1540-6261.2005.00727.x

Bencivenga, V. R., \& Smith, B. D. (1991). Financial Intermediation and Endogenous Growth, Review of Economic Studies, 58(2), 195-209. http://dx.doi.org/10.2307/2297964

Bencivenga,V. R, Smith, B. D., \& Starr, R. M. (1995). Transaction Costs, Technical Choice and Endogenous Growth, Journal of Economic Theory, 67(1), 53-177. http://dx.doi.org/10.1006/jeth.1995.1069

Bhide, A. (1993). The hidden Costs of Stock Market Liquidity, Journal of Financial Economics, 34(1), 31- 51. http://dx.doi.org/10.1016/0304-405X(93)90039-E

Blundell, R., \& Bond, S. (1998). Initial conditions and moment restrictions in dynamic panel data models, Journal of Econometrics, 87(1), 115-143. http://dx.doi.org/10.1016/S0304-4076(98)00009-8

Clark, R. (1998), Africa’s Emerging Securities Markets: Development in Financial Infrastructure. Wesport: Quorum Books

Corbett, J., \& Jenkinson, T. (1994). The Financing of Industry, 1970-1989: An International Comparison. Discussion Paper No. 948, London: Centre for Economic Policy Research.

Demirgüç-Kunt, A. \& Maksimovic, V. (1996). Stock Markets Development and Financing Choices of Firms. World Bank Economic Review, 10(2), 341-70. http://dx.doi.org/10.1093/wber/10.2.341

Dyck, A., \& Zingales, L.(2004). Private Benefits of Control: An International Comparison, Journal of Finance, 9(2), 537-600. http://dx.doi.org/10.1111/j.1540-6261.2004.00642.x

Fazzari, S. R, Hubbard, G., \& Petersen, B. C. (1988). Financing Constraints and Corporate Investment, Brookings Paper on Economic Activity, 1, 141-195. http://dx.doi.org/10.2307/2534426

Gelbard, E., \& Pereira-Leite, S. (1999). Measuring Financial Development in Sub-Saharan Africa, IMF Working Paper, Washington DC: International Monetary Fund.

Goldsmith, R. (1969). Financial Structure and Development. Yale University Press, New Haven

Greenwood, J. \&Jovanovic, B. (1990). Financial Development, Growth and the Distribution of Income, Journal of Political Economy, 98(5), 1076-1107. http://dx.doi.org/10.1086/261720

Grossman, G. M., \& Helpman, E. (1991) .Trade, knowledge spillovers, and growth, National Bureau of Economic Research Cambridge, Mass., USA.

Holmstrom, B. \& Tirole, J. (1993). Market Liquidity and Performance Monitoring, Journal of Political Economy, 101(4), 678-709. http://dx.doi.org/10.1086/261893 
Jalloh, M. (2014). Financial sector reforms and economic growth: the West African experience, Afro-Asian Journal of Finance and Accounting, 4(2), 163-181. http://dx.doi.org/10.1504/AAJFA.2014.063762

Jayarantne, J., \& Strahan, P. (1996). The Finance-Growth Nexus: Evidence from Bank-Branch Deregulation, Quarterly Journal of Economics, 111(3), 639-70. http://dx.doi.org/10.2307/2946668

King, R. G, \& Levine, R. (1993a).Finance and Growth: Schumpeter Might Be Right. Quarterly Journal of Economics, 108(3), 717-38. http://dx.doi.org/10.2307/2118406

King, R. G., \& Levine, R. (1993b). Finance, Entrepreneurship and Growth; Theory and Evidence, Journal of Monetary Economics, 32(3), 513-42. http://dx.doi.org/10.1016/0304-3932(93)90028-E

Levine, R. (1991). Stock Markets, Growth, and Tax Policy. Journal of Finance, 46 (4), 1445 -65. http://dx.doi.org/10.1111/j.1540-6261.1991.tb04625.x

Levine, R., \& Zervos, S. (1998a). Stock Markets, Banks, and Economic Growth, American Economic Review, 88(3), 537-558. http://dx.doi.org/10.1016/S0304-3932(00)00017-9

Levine, R., Loayza, N., \& Beck, T. (2000). Financial Intermediation and Growth: Causality and Causes, Journal of Monetary Economics, 46(1), 31-77.

Love, I. (2003). Financial Development and Financing Constraint: International Evidence from the Structural Investment Model, Review of Financial Studies, 16(3), 765-791. http://dx.doi.org/10.1093/rfs/hhg013

Mayer, C. (1990). Financial Systems, Corporate Finance and Economic Development. In Glenn Hubbard (Ed) Asymmetric Information, Corporate Finance and Investment. University of Chicago Press, Chicago, 307-332. http://www.nber.org/chapters/c11477.pdf

Montiel, P. J. (1996). Financial Policies and Economic Growth: Theory, Evidence and Country-Specific Experience from Sub-Saharan Africa, Journal of African Economies, Centre for the study of African Economies (CSAE), 5(3), 65 -98.

Mohtadi, H., \& Agarwal, S. (2004). Stock Market Development and Economic Growth: Evidence from Developing Countries, Oxford University Press, New York.

Ndikumana, L. (2001). Financial Markets and Economic Development in Africa. Working Paper Series No 17, Political Economy Research Institute, University of Massachusetts, Amherst.

Nissanke, M., Aryeetey, E., Hettige, H., \& Steel, W. F. (1995). Financial Integration and Development in Sub-Saharan Africa, Washington D.C. World Bank. Mimeo.

Pagano, M. (1993) .Financial Markets and Growth: An Overview. European Economic Review, 37(2), 613-22. http://dx.doi.org/10.1016/0014-2921(93)90051-B

Rajan, R., \& Zingales, L. (1998). Financial Dependence and Growth. The American Economic Review, 88 (3), 559-586.

Robinson, J. (1952). The Rate of Interest and Other Essays (London: Macmillan)

Romer, P. M. (1990). Endogenous Technical Change, Journal of Political Economy, 98 (5), 71-102. http://dx.doi.org/10.1086/261725

Schumpeter, J. A. (1969). The Theory Of Economic Development, Oxford: Oxford University Press.

Senbet, L.W., \& Otchere, I. (2005). Financial Sector Reforms in Africa: Perspectives on Issues and Policies, Annual World Bank Conference on Development Economics (ABCDE), Dakar, Senegal. http://siteresources.worldbank.org/INTABCDEWASHINGTON2005/Resources/LemmaSenbet-final.pdf

Singh, A. (1997). Stock Markets, Financial Liberalization and Economic Development. Economic Journal, 107(442), 771-82. http://dx.doi.org/10.1111/j.1468-0297.1997.tb00042.x

Spears, A. (1992). The Role of Financial Intermediation in Economic Growth in Sub-Sahara Africa, Canadian Journal of Development Studies, 13(3), 361-380. http://dx.doi.org/10.1080/02255189.1992.9669467

Stiglitz, J. E., \&Weiss, A. (1981). Credit Rationing in Markets with Imperfect Information, Oxford Review of Economic Policy, 5(4), 55-68. http://dx.doi.org/10.1093/oxrep/5.4.55

Stiglitz, J.E. (1985). Credit Markets and the Control of Capital, Journal of Money, Credit and Banking, 17(2), 133-152. http://dx.doi.org/10.2307/1992329

UNCTAD (1998).World Investment Report (various issues, 1992 to 2000). New York: United Nations Publications.

\section{(cc) $\mathrm{EY}$}

This work is licensed under a Creative Commons Attribution 3.0 License. 